\title{
Lower urinary tract symptoms associated with prostatitis
}

\author{
J. Curtis Nickel, MD, FRCSC
}

Professor, Department of Urology, Queen's University, and Tier 1 Canadian Institutes of Health Research Canada Research Chair in Urologic Pain and Inflammation, Kingston, ON

Cite as: Can Urol Assoc J 2012;6(5):S133-5. http://dx.doi.org/10.5489/cuaj.12201

\section{Abstract}

Approximately $50 \%$ to $60 \%$ of men with chronic prostatitis experience troublesome lower urinary tract symptoms (LUTS). Individual interventions yield statistically significant but minimally important improvements in clinical trials. Research has shown that categorizing patients with prostatitis by phenotype is an effective way to rationally select therapy and maximize the impact on symptom reduction and improve quality of life.

$\mathrm{L}$ ower urinary tract symptoms (LUTS) associated with pain (e.g., prostatitis) tend to have a more substantial impact on patient quality of life than other LUTS presentations. There are several categories of prostatitis, each with their own clinical profile in terms of the expected symptom types (pain, voiding, storage). Furthermore, one can characterize the types of symptoms seen in prostatitis through the use of a novel mnemonic (UPOINT). Making treatment decisions according to the presence or absence of each of the UPOINT symptom types has been associated with excellent results. The following review outlines this phenotypic approach to prostatitis and the results that have been reported to date when treating according to this approach.

\section{LUTS and pain in prostatitis: Overview}

There are four categories of prostatitis: acute bacterial prostatitis (category I), chronic bacterial prostatitis (category II), chronic prostatitis/chronic pelvic pain syndrome (category III), and asymptomatic prostatitis (category IV). Each of these categories has a different profile with respect to LUTS (Table 1).

Overall, investigation of an international prostatitis database showed that $50 \%$ to $60 \%$ of men in the database had urinary LUTS. ${ }^{1}$ The most common sites of pain were perineal $(63.3 \%$ of patients), and testicular (57.6\%). Other commonly reported sites were ejaculatory pain $(44.7 \%)$, dysuria $(43.3 \%)$, pubic area $(42.3 \%)$ and the tip of the penis $(32.4 \%) .^{1}$ The most bothersome of these was ejaculatory pain. The variables found to be associated with reduced quality of life in this study were increased pain severity, increased pain frequency and number of pain localizations.

\section{Recommended evaluation of prostatitis}

The Canadian Urological Association (CUA) guidelines ${ }^{2}$ on prostatitis, published in 2011, recommend that the evaluation of men with symptoms of prostatitis include a detailed history and, for chronic cases, the use of the National Institutes of Health chronic prostatitis symptom index (NIH-CPSI). ${ }^{3}$ In the history, the assessment should include characterization of pain (location, severity, frequency, and duration) and LUTS (obstructive/voiding and irritative/storage), as well as other associated symptoms (e.g., fever, other pain syndromes) and the impact of the symptoms on activities and quality of life. Furthermore, the comprehensive systems review should document past medical and surgical (particularly urologic) history, history of trauma, medications and allergies.

Use of the NIH-CPSI is important in that it affords patients the opportunity to tell their physician how severe they perceive their pain or symptoms to be. It is also useful as a way to measure change over time and monitor the effectiveness of treatment.

\section{Prostatitis treatment}

For chronic prostatitis and chronic pelvic pain syndrome, the CUA guidelines include a treatment algorithm that outlines a number of

Table 1. Lower urinary tract symptoms associated with prostatitis

\begin{tabular}{|c|c|c|c|}
\hline Category & Pain & Voiding & Storage \\
\hline $\begin{array}{l}\text { I } \\
\text { Acute bacterial } \\
\text { prostatitis }\end{array}$ & $\begin{array}{l}\text { Acute } \\
++++\end{array}$ & $\begin{array}{c}\text { Acute } \\
+++\end{array}$ & $\begin{array}{c}\text { Acute } \\
+++\end{array}$ \\
\hline $\begin{array}{l}\text { II } \\
\text { Chronic bacterial } \\
\text { prostatitis }\end{array}$ & $\begin{array}{c}\text { Intermittent } \\
+++\end{array}$ & $\begin{array}{c}\text { Intermittent } \\
\text { or } \\
\text { persistent } \\
++\end{array}$ & $\begin{array}{c}\text { Intermittent } \\
\text { or } \\
\text { persistent } \\
++\end{array}$ \\
\hline $\begin{array}{l}\text { III } \\
\text { Chronic prostatitis/ } \\
\text { chronic pelvic pain } \\
\text { syndrome }\end{array}$ & $\begin{array}{c}\text { Chronic } \\
++\rightarrow++++\end{array}$ & $\begin{array}{l}\text { Chronic } \\
0 \rightarrow++\end{array}$ & $\begin{array}{c}\text { Chronic } \\
0 \rightarrow++\end{array}$ \\
\hline $\begin{array}{l}\text { IV } \\
\text { Asymptomatic } \\
\text { prostatitis }\end{array}$ & None & $\begin{array}{c}\text { Possible } \\
0 \rightarrow++\end{array}$ & $\begin{array}{c}\text { Possible } \\
0 \rightarrow++\end{array}$ \\
\hline
\end{tabular}


Nickel

different treatment modalities (Fig. 1). ${ }^{2}$ Taken individually, each of these interventions has been shown to have a statistically significant, but not necessarily clinically relevant, beneficial impact on symptoms. ${ }^{4}$ Collectively, however, use of the appropriate treatments can have a substantial benefit on symptoms and overall quality of life. Avoidance of any identified causes or triggers is also an important part of overall management.

\section{UPOINT}

As mentioned above, there is now a novel approach to the characterization of patients with prostatitis that seeks to maximize the impact of pharmacotherapy through the identification of specific phenotypes that are likely to respond to a given therapy. The UPOINT mnemonic stands for Urinary, Psychosocial, Organcentric, Infection, Neurogenic/systemic and Tenderness. Research has shown that if patients are identified by UPOINT phenotype and treated accordingly (Fig. 2), there is an $84 \%$ response rate (response defined as a six-point fall in CPSI), with a CPSI decrease of 12 points, from 25.2 to $13.2 .^{5}$

\section{Conclusion}

Traditional therapies for LUTS associated with chronic pelvic pain syndrome can be effective if they are used in new evidence- and rationale-based strategies.

Competing interests: Dr. Nickel is a paid consultant for Astellas, GlaxoSmithKline, Taris, Ferring, Watson, Johnson and Johnson, Eli Lilly, Farr Labs, and Triton.

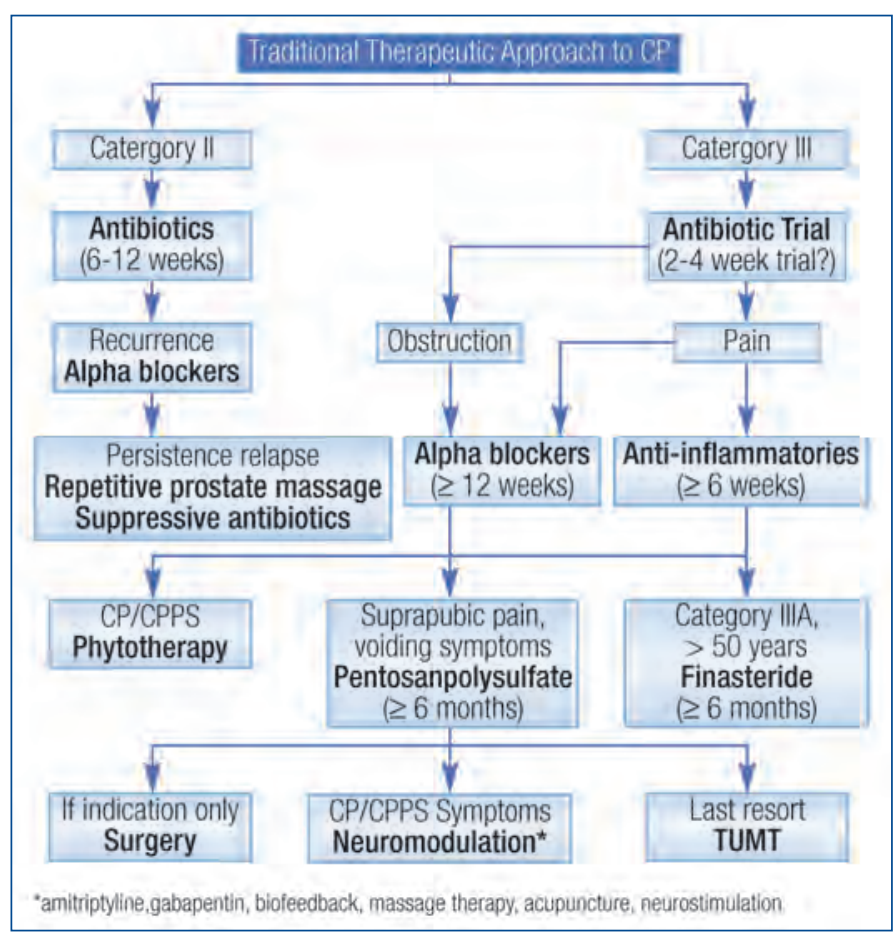

Fig. 1. Algorithm for the Treatment of Symptomatic Chronic Prostatitis. Adapted from Nickel. Prostatitis. Can Urol Assoc J 2011;5:306-15.

\section{References}

1. Wagenlehner F, van Till 0, Magri V, et al. National Institute of Health Chronic Prostatitis Symptom Index (CPSI) symptom evaluation in patients with chronic prostatitis / chronic pelvic pain syndrome - A multinational study in 1,563 patients. Presented at AUA 2012, abstract \#1082.

2. Nickel IC. Prostatitis. Can Urol Assoc J 2011;5:306-15. http://dx.doi.org/10.5489/cuaj.11211

3. Litwin MS, McNaughton-Collins M, Fowler FJ Jr, et al. The National Institutes of Health chronic prostatitis symptom index: development and validation of a new outcome measure. Chronic Prostatitis Collaborative Research Network. J Urol 1999;162:369-75. http://dx.doi.org/10.1016/S0022-5347(05)68562-X

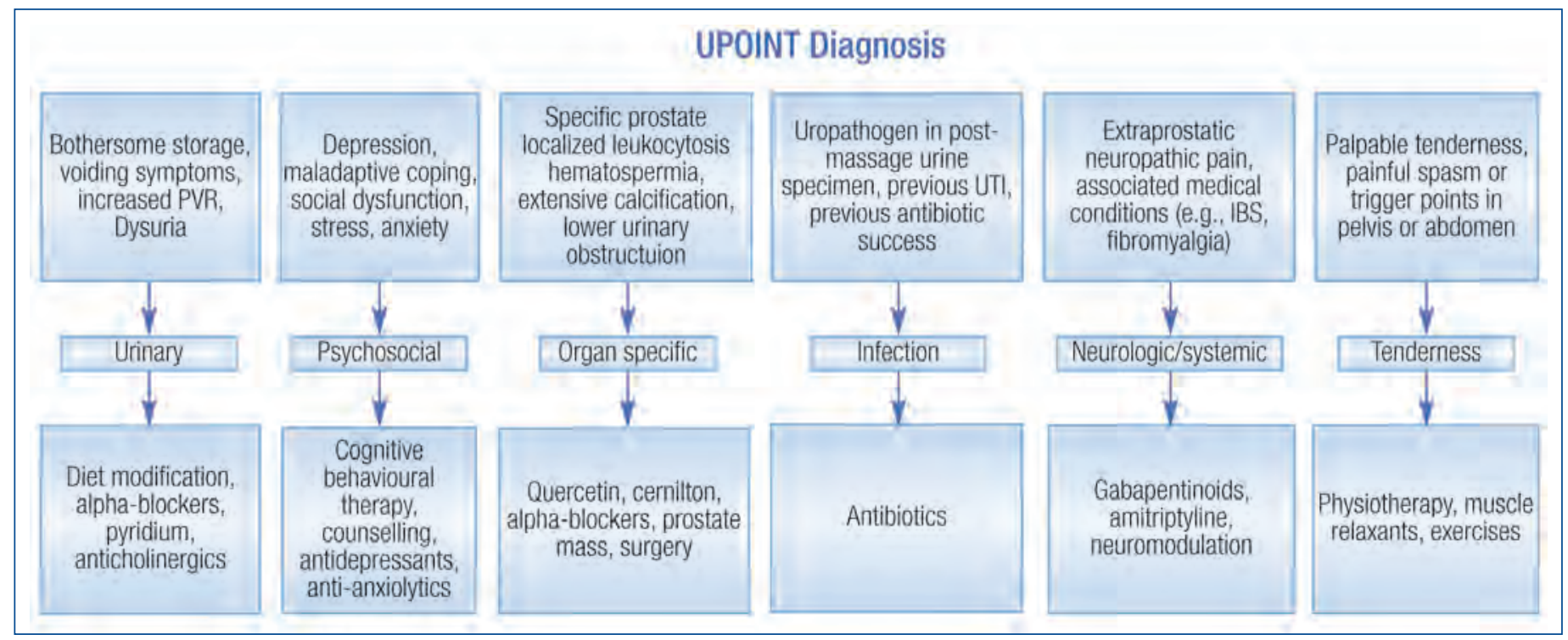

Fig. 2. UPOINT: Phenotypic Approach to Treating Prostatitis. Adapted from Nickel. Prostatitis. Can Urol Assoc J 2011;5:306-15. 
4. Anothaisintawee T, Attia J, Nickel JC, et al. Management of chronic prostatitis/chronic pelvic pain syndrome: a systematic review and network meta-analysis. JAMA 2011;305:78-86. http://dx.doi. org/10.1001/jama.2010.1913

5. Shoskes DA, Nickel JC, Kattan MW. Phenotypically directed multimodal therapy for chronic prostatitis/ chronic pelvic pain syndrome: a prospective study using UPOINT. Urology 2010;75:1249-53. http:// dx.doi.org/10.1016/j.urology.2010.01.021
Correspondence: Dr. J. Curtis Nickel, Department of Urology, Victory 4 - 76 Stuart St., Kingston, ON K7L 2V7; icn@queensu.ca 